\title{
Behaviour and energetics of ice-breeding, North Atlantic phocid seals during the lactation period
}

\author{
Christian Lydersen ${ }^{1, *}$, Kit M. Kovacs ${ }^{1,2}$ \\ ${ }^{1}$ Norwegian Polar Institute, 9296 Tromsø, Norway \\ ${ }^{2}$ Department of Biology, UNIS, 9170 Longyearbyen, Norway
}

\begin{abstract}
This review presents a comparative analysis of the behaviour and energetics of the icebreeding phocid seals of the North Atlantic in relation to their habitat(s). In very broad terms, it suggests that the term 'ice-breeding' is too simplistic and may lead to misconceptions about the actual degree of variability that exists in the breeding habitats of seals that do not give birth an land. The variation that exists within ice habitats is quite remarkable in terms of: temporal and structural stability of the pupping platform; the degree to which animals have access to the water; the risk of predation; and perhaps also the local availability of food. These factors all appear to influence the behaviour of mothers and pups and the allocation of energy during the lactation period of the species studied. Two basically different nursing strategies can be identified that may have evolved, at least in part, as a consequence of variation in these variables. The pattern displayed by grey (Halichoerus grypus), harp (Phoca groenlandica) and hooded (Cystophora cristata) seals involves a short lactation period, during which a large amount of energy is transferred from the mother to the pup through extremely-energy-rich milk. Pups of these species are very inactive and consequently a very high proportion of the received energy can be stored as body tissue, mainly in the form of subcutaneous blubber. The mothers generally feed little or not at all during the nursing period and the pups are weaned abruptly, having not yet entered the water in most cases. The other strategy, found in bearded (Erignathus barbatus) and ringed (Phoca hispida) seals, involves a longer lactation period, where less-energy-rich milk is transferred to very active pups. These pups learn to swim and dive during the nursing period, and are weaned with body compositions that are similar to those of adults. The mothers feed during lactation and weaning is less abrupt, with pups feeding independently, while still receiving milk from their mothers.
\end{abstract}

KEY WORDS: Behaviour - Diving - Lactation - Maternal investment Ice-breeding seals

\section{INTRODUCTION}

The pinnipeds are comprised of 3 families, the true seals (Phocidae), the eared seals (Otariidae) - which include the fur seals and sea lions - and the walruses (Odobenidae). There is ongoing discussion as to whether this group of animals stems from a common ancestor or whether it has divergent roots (e.g. McLaren 1960, Ray 1976, Repenning 1976, 1980, Tedford 1976, Repenning et al. 1979, Muizon 1982, Arnason \& Widegren 1986, Wyss 1988). Currently, a mono-

•E-mail: lydersen@npolar.no phyletic origin, from an early seal-like animal, Enaliarctos mealsi, appears to be favoured (Berta et al. 1989), although this view is far from universal (see Barnes et al. 1985, Bonner 1989). Regardless of the precise affinities among the pinnipeds, it is clear that the earliest phocid fossils are from the mid- to late Miocene (12 to 15 million yr ago) and were found in the North Atlantic (True 1906, Lipps \& Mitchell 1976, Barnes et al. 1985).

The fossil record for phocids is extremely fragmentary, but the oldest phocoid fossils are clearly divisible into 2 lineages, the monachines and the phocines, both of which are derived from 1 common ancestor (see Repenning et al. 1979). It is also clear that the early 
phocine seals had a northerly preference, while the early monachines were more southerly. The latter group gave rise to the elephant seals Mirounga spp., the monk seals Monachus spp. and the Antarctic phocids (and perhaps also the bearded seal Erignathus barbatus - see Perry et al. 1995) that spread through the Isthmus of Panama into the Pacific and southward down the west coast of South America (Repenning et al. 1979). Meanwhile, the phocine seals, which gave rise to all of the northern phocids, exploited the opportunities offered by the cold waters of the north during the period of progressive cooling 15 to 5 million yr ago (Repenning et al. 1979, Repenning 1980).

Stirling (1983) suggests that the formation of pack ice and land-fast ice along coastlines would have made the shore less accessible to seals for breeding purposes, resulting in some seals adapting their behaviour to breed and feed in association with the ice. The virtually unlimiled amount of space in the ice habitat released females from the need to aggregate as tightly as they did on land. Concomitantly, males were less able to control large numbers of females and thus the degree of polygyny, and sexual dimorphism was reduced (Bartholomew 1970, Stirling 1975, 1983). Contimuous breeding on ice seems to have created selection pressures for short synchronised periods for birth, weaning and mating, and a promiscuous or mildly polygynous mating system, reduced disparity in body sizes of the sexes and similar mortality rates of adult males and females (Stirling 1975). However, the constraints imposed by the fundamental dichotomy of having young that are dependent on a solid substrate for a period while adults must secure food at sea remain, and continue to largely determine, the basic social systems and set-up for the period of neonatal dependence among even the ice-breeding pinnipeds.

Because seals disperse to varying degrees to feed aquatically, and have limited access to suitable habit for parturition, females have developed strong site fidelity to pupping sites and they mate shortly after parturition (Stirling 1975, 1983). Seal mothers either cycle periods of maternal care with foraging excursions or they perform a highly concentrated, brief period of lactation (Bonner 1984, Gentry \& Kooyman 1986). All phocid seals have evolved the latter strategy and most phocid seals (13 out of 18 species) give birth on ice (Bowen 1991). However, even within the icebreeders the relative stability of the breeding habitat has a profound influence on the attendance pattern of mothers during lactation and the nature and duration of mother-pup interactions (Stirling 1975, Kovacs \& Lavigne 1986, Oftedal et al. 1987). Species that pup in unstable drifting ice, such as harp (Phoca groenlandica) and hooded (Cytophora cristata) seals have very short nursing periods, averaging only 12 to 13 and
3 to 4 d, respectively (Bowen et al. 1985, Kovacs 1987 a), while species pupping in fast ice habitats like ringed (Phoca hispida) and Baikal (Phoca sibirica) seals nurse their pups for up to 2 mo (Lydersen \& Hammill 1993a, Pastukhov 1975). However, this general pattern in habitat versus lactation duration does not explain all of the observed variation during the period of nutritional dependence for phocid seals. For example, bearded seal pups are reared in very unstable drifting ice and thus would be expected to nurse for a very short time, and not for the period of $24 \mathrm{~d}$ that appears to be the norm (see below). Clearly, other factors must also be taken into account. The duration of lactation is known to be correlated to some degree with other major features of the ecology and behaviour of the neonate (Bowen 1991) and predation pressure or the lack of it is thought to have a dominant influence on the behaviour of both adult and neonatal pinnipeds (Stirling 1977)

The principal aim of this review is to provide an integrated examination of the impact of habitat variation among ice types used by phocid seals, in a broad sense, in relation to the behavioural and energetic strategies employed by pups and their mothers during the lactation period. It focuses principally on the phocid species of the North Atlantic, including the bearded seal, grey seal (Halichoerus grypus), harp seal hooded seal and ringed seal (Table 1). Pups of 4 of these 5 species are born on drifting floe ice. The fifth species, the ringed seal, breeds primarily on land-fast ice. Phocid seals other than the 5 North Atlantic icebreeders are examined only in a general comparative context in this review. The specific aspects of lactation or ecophysiology covered herein differ somewhat from species to species, in a fashion that compliments the existing scientific literature for the various species in the North Atlantic.

\section{PUPPING HABITAT(S)}

The 5 species featured in this review all give birth on ice (Table 1). However, the social and physical conditions of their respective pupping habitats are remarkably variable. Ice-breeding grey seals aggregate to give birth in January, when only near-shore, thin ice has formed. They use ice that is located in bays or ice that has rafted against islands, or shallow-coastal shoals (Lydersen et al. 1994a, Tinker et al. 1995, Haller et al. 1996). Access to the water is highly variable depending on the degree of rafting and breakage of the ice. Grey seal pups are born on the ice within colonies, at densities that are similar to land-breeding populations of this species, despite the abundance of potential pupping substrate for ice breeders. Groups 
Table 1. Breeding area and pup characteristics for North Atlantic, ice-breeding seals

\begin{tabular}{|c|c|c|c|c|c|c|}
\hline Species & Study area & $\begin{array}{l}\text { Peak pupping } \\
\text { period }\end{array}$ & Habitat & $\begin{array}{l}\text { New-born pelage } \\
\text { characteristics }\end{array}$ & $\begin{array}{l}\text { Duration of } \\
\text { lactation (d) }\end{array}$ & Weaning \\
\hline Bearded seals & Svalbard & 1st wk of May & Floe ice & Blue/grey semi-molted & $24^{\mathrm{a}}$ & Gradual \\
\hline Grey seals & Gulf of St. Lawrence & 1st wk of Jan & Floe ice & White lanugo & $15^{\mathrm{b}}$ & Abrupt \\
\hline Harp seals & Gulf of St. Lawrence & 1st wkof Mar & Floe ice & White lanugo & $12^{c}$ & Abrupt \\
\hline Hooded seals & Gulf of St. Lawrence & 3rd wk of Mar & Floe ice & Blue/grey molted & $3.1^{d}$ & Abrupt \\
\hline Ringed seals & Svalbard & 1st wk of Apr & Fast ice (lairs) & White lanugo & $39^{e}$ & Gradual \\
\hline
\end{tabular}

may be as large as several hundred adults (pers. obs.). Adult males are scattered at low densities through the herd, each defending a small group of females (Tinker et al. 1995). Mother-pup pairs are spaced such that nearest-neighbour distances are 5 to $10+m$ (Bedard 1993). Harp seals in the Gulf of St. Lawrence, and elsewhere, give birth in vast herds, located in regions of extensive, free-floating pack ice that is not adjacent to land. This ice is first-year ice and is relatively thin. Females aggregate in small clusters, near floe edges or along cracks in the ice (Stewart 1987). Inter-neighbour distances are similar to those of grey seals (Kovacs 1995a, pers. obs.). Males haul out together in small, tight groups, and do not regularly intersperse among females (Lavigne \& Kovacs 1988). Only under exceptional circumstances would adults not have ready access to open water through holes that they maintain if cracks start to freeze. Hooded seals breed very late in the pack-ice season, when the ice is highly mobile because the pack is disappearing. Female hooded seals choose large floes when they are available in the Gulf of St. Lawrence and actively move considerable distances away from the edges of the ice, into central areas. Hooded seal mothers aggregate in recognisable herds, but there is a greater nearest-neighbour distance in this species compared to grey seals or harp seals. It is normal for female hooded seals to be spaced at 50 to $100+\mathrm{m}$ intervals (Boness et al. 1988, Kovacs 1990). Hooded seals tend to select heavier ice than harp or grey seals, and do not maintain holes because females do not go to the water during lactation. Adult males attend individual mother-pup pairs, such that the herds are composed of trios. Bearded seals females do not form herds. Individual females give birth on very small ice floes in loose, free-floating, coastal pack ice in the high Arctic (Kovacs et al. 1996). They always have immediate access to the water. It is not uncommon for bearded seal mother-pup pairs to be isolated from one another by distances of a few kilometres. Ringed seals also give birth in the high Arctic, in ex- tensive regions of pack ice or most commonly in areas of land-fast ice. This species digs subnivean birth lairs in snow drifts, above breathing holes which they actively maintain (Smith \& Stirling 1975). Thus, they always have access to the water, and pups also have some thermal protection.

\section{PREDATION RISK}

All North Atlantic phocid seals are preyed upon to some degree by killer whales Orcinus orca and perhaps also by Greenland sharks Somniosus microcephalus. Additionally, walruses Odobenus rosmarus are known to consume both adults and young of all phocid species with overlapping distribution ranges. However, the impact of aquatic predation is difficult to address because it is rarely observed, although it likely occurs frequently.

Breeding in dense aggregations in isolated locations is thought to have developed evolutionarily as an antipredator strategy in grey, harp and hooded seals. Grouping is a functional strategy to counter modest levels of surface predation. Since predators tend to seize the first individuals they encounter and eventually reach satiation, there is a great advantage to being in the centre of a large group (Wilson 1975). The short lactation periods of these species may also be related to predation avoidance. But, these 3 species are not subject to high degrees of surface predation in modern times. Near-shore grey seals may attract attention from terrestrial or avian predators such as foxes, coyotes or eagles, but these predators would have great difficulty killing the relatively large, aggressive grey seal pups. Additionally, a predator would have to contend with a group of aggressive mothers, each of which weighs hundreds of kilograms. Thus, surface predation is unlikely to be a significant cause of mortality for grey seals. Harp and hooded seals in the Gulf of St. Lawrence are not currently exposed to polar bear 
Ursus maritimus predation, although it is thought that polar bears did come into the Gulf regularly as recently as a few hundred years ago. However, other breeding areas of these 2 species do make marginal contact with the polar bear's distribution, so, although confrontations are not very common, they do occur. When polar bears enter a harp seal breeding area, they can create a serious local impact. Harp seal pups are relatively small and basically defenceless against a bear. Adult harps seals are also common prey of polar bears, so maternal defence would not be an effective strategy Polar bear predation on hooded seals is only rarely reported (Nansen 1898) and, although the general literature on seals (e.g. King 1983, Reeves et al. 1992) always seems to mention them as a predator, it is unlikely that they are a major source of mortality for this species. Other, smaller, potential predators would have difficulties accessing the hooded seal pups since they are born weighing more than $20 \mathrm{~kg}$ and are valiantly defended by their mothers until they weigh about $50 \mathrm{~kg}$. Hooded seal mothers were commonly killed by sealers while defending their young, prior to legislation by most sealing nations restricting this activity. However, it is unlikely that maternal defence would be able to dissuade a determined polar bear, and the passive neonates have no specific means of defence. However, the extreme brevity of the nursing period limits the availability of hooded seal pups to surface predators. Thus, it is unlikely that predation, other than by humans, has a great influence on grey, harp and hooded seals, in their isolated, pack-ice habitats in modern times.

The global distributions of the pupping habitats of bearded and ringed seals are more northerly than the other ice-breeding phocids described above. These 2 species occur concomitantly with the range of polar bears, and both adults and pups of these 2 species are major components of the diet of polar bears (Stirling 1974, Stirling \& Latour 1978, Smith 1980, Gjertz \& Lydersen 1986a). Ringed seal pups are afforded some protection from surface predators by being in their snow lairs when they are young, but despite this snowcover they remain a favourite prey item for polar bears in the spring. Because of their small body, and accessibility from land, ringed seals neonates are also subject to heavy predation pressure from arctic foxes Alopex lagopus (Smith 1976, Lydersen \& Gjertz 1986). In some years, or in areas where ringed seals are born outside lairs, even avian predation occurs (Lydersen \& Smith 1989). Bearded seals are afforded some protection by their large body size and the fact that predators must swim to reach them, but polar bear predation on this species is significant. Predation by polar bears is thought to have a profound effect on virtually all aspects of the reproductive ecology of these 2 species.

\section{BEHAVIOURAL CHARACTERISTICS OF NEONATES}

Unfortunately, relatively few quantitative studies have been conducted on the behaviour of phocid seal neonates. However, early behavioural development of several of the species that are the principle subjects of this review have received focused attention and a few comparative studies are also available. It is clear that the neonates of all of the ice-breeding phocid seals must be considered extremely precocial, both physically and behaviourally. They are born with their eyes open, and are able to vocalise, move around and suckle often within minutes after birth (Bowen 1991). However, they do display considerable variation with respect to their behavioural patterns during the nursing period (Table 2).

Grey seal pups born on ice do not normally enter the water during the nursing period (Haller et al. 1996). They spend more than $70 \%$ of their time idle or asleep, and only about $4 \%$ of the time moving around on the ice (Haller et al. 1996). Pups are cared for by their mothers in a manner similar to land-breeding populations, but the nursing period is somewhat more intense and is shorter on the ice compared to that of terrestri-

Table 2. Activity budgets of pups and maternal on-ice attendance data for North Atlantic, ice-breeding seals

\begin{tabular}{|c|c|c|c|c|c|c|}
\hline Species & $\begin{array}{l}\text { Pup time } \\
\text { on ice }(\%)\end{array}$ & $\begin{array}{l}\text { Maternal time } \\
\text { on ice }(\%)\end{array}$ & $\begin{array}{c}\text { Time between } \\
\text { nursing bouts }(h \pm S D)\end{array}$ & $\begin{array}{c}\text { Pup time } \\
\text { in water }(\%)\end{array}$ & $\begin{array}{l}\text { Pup time } \\
\text { at surface }(\%)\end{array}$ & $\begin{array}{c}\text { Pup time } \\
\text { submerged }(\%)\end{array}$ \\
\hline Bearded seals & $47^{\circ}$ & $16^{r}$ & $2.2 \pm 2.4^{d}$ & $53^{\mathrm{a}}$ & $58^{\mathrm{a}}$ & $42^{d}$ \\
\hline Grey seals & 100 & $72^{d}$ & $3.3 \pm 1.2^{9}$ & 0 & 0 & 0 \\
\hline Harp seals & 100 & $29^{e}$ & $3.9 \pm 1.5^{\mathrm{h}}$ & 0 & 0 & 0 \\
\hline Hooded seals & 100 & 100 & $0.42^{1}$ & 0 & 0 & 0 \\
\hline Ringed seals & $50^{\mathrm{b}}$ & $18^{f}$ & $8.2 \pm 3.2^{b}$ & $50^{b}$ & $80^{b}$ & $20^{\mathrm{b}}$ \\
\hline
\end{tabular}


ally breeding grey seals (e.g. Kovacs 1987 b, Lydersen et al. 1994a, Haller et al. 1996). Grey seal pups in ice habitats are attended by their mothers approximately $75 \%$ of the time during the lactation period (Lydersen et al. 1994a) and they are nursed about every $3 \mathrm{~h}$ (Lydersen et al. 1994a, Haller et al. 1996). Pups of this species are very aggressive, and they attempt to defend themselves against intraspecific or interspecific intruders

Harp seal pups also generally spend all of their time on the ice during the nursing period (Kovacs 1987a). Pups of this species are also very sedentary, spending from 60 to $85 \%$ of the their time idle or asleep. Depending on pup age, 2 to $8 \%$ of their time is spent actively moving around (Kovacs 1987a). Surprisingly, this locomotory behaviour actually decreases with increasing pup age. The pups are attended on the ice by their mothers for only 20 to $30 \%$ of the time (Lydersen \& Kovacs 1993, 1996), and are nursed approximately every 4 h (Lydersen \& Kovacs 1993). Harp seal pups have a marked predator response that is very unlike that of grey seal pups. When harp seal pups feel threatened, they display a fear paralysis. Their bodies become stiff and their heads are retracted into the fat sheath that encompasses their body, thereby protecting the skull to some degree. They urinate and often defecate. Additionally, they stop breathing and profoundly drop their heart rates (Lydersen \& Kovacs 1995). This dramatic response may actually afford them some protection from polar bears. Bears observed entering the whelping patches of harp seals, faced with a superabundance of food, often play with the pups. They throw them into the air, and bite many, while eating relatively few (Nansen 1925). Pups that perform the freeze response appear to be less interesting to the bears than those that try to escape, so they receive less attention. This may allow them to survive the trauma of a quick bite and a toss as opposed to more prolonged interactions.

Hooded seal mother-pup pairs remain together on the ice surface throughout the short nursing period of this species (Bowen et al. 1985, 1987, Kovacs \& Lavigne 1992, Kovacs 1995b). Pups are very sedentary and spend most of their time asleep, within a meter of their mothers (Kovacs et al. unpubl. data). They move only to approach the female for nursing, or when the pair is disturbed by the activities of adult males. Perry \& Stenson (1992) suggested that hooded seal pups spend $18 \%$ of their time nursing. The passive neonates have no specific means of defence, other than their very attentive, large mothers. Weaned pups do become aggressive (Lydersen \& Kovacs unpubl. data), which might be effective against small predators, but against polar bears this sort of resistance would not have an impact.
The early postnatal period of these 3 phocid seals appears to be dominated by the need for a rapid transfer, and retention, of energy (see 'Physical characteristics of neonates and pup energetics'). Despite the precocial nature of the phocid pups at birth, these neonates spend most of their time sleeping or nursing. This basic pattern is not unusual among mammals, but the proportion of time spent completely idle in the case of these phocids tends toward an extreme. Among these species, pups are frequently weaned within a few meters of their birth locations. Another somewhat unusual feature of pup behaviour among these highly social ice-breeding phocids is the solitary nature of early neonatal development. Pups of all 3 of these species interact almost exclusively with only their mothers during the nursing period, despite the proximity of conspecifics. Even the limited play behaviour performed by phocids during the nursing period is normally object directed, and solitary (e.g. Wilson 1974, Renouf \& Lawson 1986, 1987, Kovacs 1987a,b). Interactions among pups are rare, and are usually brief and aggressive when they do occur (Rasa 1971, Reiter et al. 1978, Sullivan 1982, Kovacs 1987 a,b). The sedentary, non-social nature of these pups minimises energy expenditure. By being inactive and sleeping a lot pups reduce their metabolic costs (Worthy 1987), and thereby maximise the amount of milk energy that can be used to build muscle and blubber. They also minimise the risk of premature separation from their mothers or the risk of maternal confusion in milk delivery.

Not all ice-breeding phocid pups are sedentary to the extreme extent described above. In fact, there is quite a distinct dichotomy among the ice-breeding phocids featured in this review. Pups of some species remain quietly awaiting the next meal delivery on the surface while others are active swimmers and divers during the nursing period. Bearded seal and ringed seal pups belong to the active minority, being 2 of 6 phocid species that enter the water prior to weaning.

Bearded seal pups enter the water very shortly after birth (Kovacs et al. 1996), possibly to remove the pup from the area marked by the sight and smell of the birth blood which could attract predators. Harassment by glaucous gulls Larus hyperboreus eating the placenta and birth blood may also play a role in the early departure from the place of birth (pers. obs.). During the first few days of life, bearded seal pups seem to spend most of their time on the ice surface, but by the time they are just a few days old, they spend approximately half of their time in the water (Table 2). Bearded seal pups are idle or asleep $55 \%$ of the time that they are on the ice, which means approximately $25 \%$ of the total time (Holsvik 1998). Less than $3 \%$ of their time is spent actively moving around on the surface, or engaged in other active behaviours, such as play. 
While bearded seal pups are hauled out they are accompanied by their mothers an average of $33 \%$ of the time. However, mothers spend about $60 \%$ of their total time in close proximity to the pup, often resting at the surface of the water next to the ice floe where the pup is hauled out. Bearded seal pups are virtually never found more than a body length from the water. When pups are alone, they always lay at the edge of the ice, and they face the water (Kingsley \& Stirling 1991, pers. obs.). Bearded seal pups are much more alert than the species described above (Holsvik 1998). If they are surprised or threatened, a quick movement with the foreflippers lands them in the water. Only when mothers haul out to nurse them do they move more than a meter from the water. Bearded seal pups nurse for approximately $10 \mathrm{~min}$ every 2 to $3 \mathrm{~h}$ (Lydersen et al. 1994b, Holsvik 1998). As pups get older, they spend more of their time in the water. Their diving capabilities are not very well developed at first, but they improve quickly. A significant positive correlation between dive duration and age can be seen on a dayto-day basis during the nursing period (Lydersen et al. 1994b). Most bearded seal pup dives are shallow and of short duration, with mean values of $10 \pm 10 \mathrm{~m}$ and 62 $\pm 46 \mathrm{~s}$, respectively (Lydersen et al. 1994b). The maximum values that have been recorded for these parameters are $84 \mathrm{~m}$ and $5.5 \mathrm{~min}$. These maximum records may not seem very impressive, but when the age of the pups is considered they are quite remarkable. The extremely early development of swimming and diving is likely a consequence of the unstable nursing habitat of this species in concert with predation pressure. Bearded seal mother-pup pairs move over large areas; VHF-tracking of mother-pup pairs has shown that they can move $10 \mathrm{~s}$ of $\mathrm{km}$ daily depending among other factors on ice drift (Hammill et al. 1994). If the pack ice drifts offshore, the pairs leave it for more coastal waters. This may take place in order to seek the shelter of quieter inshore waters, or because the mothers feed during lactation (Lydersen et al. 1996) and most food is found in relatively shallow areas.

Little is known about the on-ice behaviour of ringed seal pups, because most of their early development takes place inside their subnivean lairs. Any disturbance of a lair makes the pup move to another structure within their territory, so attempts to observe behaviour in lairs have not been successful. However, TDRs (timedepth recorders) placed on ringed seal pups indicated that they spend $50 \%$ of their time hauled out on the ice (Lydersen \& Hammill 1993a). Based on studies of the physical structure of lairs (Smith \& Stirling 1975, Lydersen \& Gjertz 1986, Furgal et al. 1996), it is evident that pups are active during some of their in-lair time. The pups construct tunnels running of the main chamber of the lair that is build by the mother. The pup tunnels can sometimes be quite an elaborate series of structures, that may even make connections between closely situated main chambers of adjacent lair complexes. Observations of tracks at breathing holes where ringed seal pups have been hauled out suggest that they normally stay close to the hole when they are on the surface of the snow (Lydersen unpubl. data), similar to adult ringed seals (Stirling 1977, Smith 1987). The small amount of available information on activity budgets of nursing mothers of this species indicates that the pups are attended on the ice by their mothers approximately $18 \%$ of the time (Table 2) and they are nursed about 3 times per day (Lydersen \& Hammill 1993a). During the first days of life ringed seal pups are relatively defenceless and it is thought that mothers actively move the pup if the lair is attacked (Smith 1987). The small newborns survive brief immersions in cold water by burning brown adipose tissue (Taugbøl 1984). As lactation proceeds, and the pups develop a subcutaneous blubber layer, they start entering the water voluntarily (Lydersen \& Hammill 1993a, Lydersen et al. 1993). The smallest ringed seal pup handled during studies in Svalbard, captured at a breathing hole it had reached by swimming, weighed $6.4 \mathrm{~kg}$ and was estimated to be $5 \mathrm{~d}$ old (Lydersen et al. 1992a). After the first week of life, ringed seal pups spend about half of their time in the water (Lydersen \& Hammill 1993a) and once they have begun to swim it appears that their skills develop quickly. Ringed seal pups demonstrate significant daily increases in their diving skills (Lydersen \& Hammill 1993a) similar to the pattern displayed in bearded seals. Most dives recorded from nursing ringed seal pups were shallow and of short duration, with mean values of less than $10 \mathrm{~m}$ and $59 \pm 64 \mathrm{~s}$, respectively. Maximum recorded values for these parameters were $89 \mathrm{~m}$ and $12 \mathrm{~min}$ (Lydersen \& Hammill 1993a). The maximum depth values obtained corresponded to the bottom depth of the study area. Ringed seals are thought to be territorial (Smith 1987), defending underwater territories with associated breathing holes. Thus, it is not surprising that ringed seal pups do not move great distances. However, individual ringed seal pups were captured or observed at an average of $8.7 \pm 3.5$ different breathing holes during a diving study by Lydersen \& Hammill (1993a) in Svalbard. This suggests a much higher average number of breathing holes per individual in this area, compared to studies by Hammill \& Smith (1990) in the Canadian Arctic. Alternatively, it may suggest that pups are free to move into the territory of seals other than their mothers, or that territory structure of ringed seals is somewhat less rigid than is generally assumed. This latter suggestion is further reinforced by the occasional findings of 2 whitecoats within a lair (Smith \& Stirling 1975) or at breathing holes on the open ice (Lydersen et al, 1993). 
Although it is highly likely that the precocial swimming and diving skills of pups of both of these species are largely attributable to predation pressure from polar bears, there are other phocid species whose pups routinely go into the water during nursing that are not subject to high pressure from surface predators. These species include the harbour seal Phoca vitulina, the monk seals and the Weddell seal Leptonychotes weddellii. Harbour seals give birth on tidally exposed rocks through most of their distribution, so pups are usually forced to swim upon the first high tide following their birth (Renouf et al. 1983, Renouf \& Diemand 1984, Lawson \& Renouf 1987). It is not known if harbour seals pups actively dive or if they simply remain at the surface while their mothers dive, but they certainly swim when they are very young. Like bearded seals, pupping-habitat constraints may also serve to induce early swimming skills in this species. In harbour seals the energetic needs of the mothers may also have played a role in the evolution of early swimming (Boness et al. 1994). This factor may also play a role for bearded seals; mothers feed throughout lactation in this species (Lydersen \& Kovacs unpubl. data). Hawaiian (Monachus schauinslandi) and Mediterranean (Monachus monachus) monk seal pups enter the water during the nursing period, but it appears that their aquatic activities are quite limited (Kenyon \& Rice 1959, Gazo \& Cappozzo 1996). Pups of these species may enter the water primarily for thermoregulatory purposes. They are born in hot climates, on sandy beaches that offer little shade, and they have dark pelage. Weddell seals breeds on land-fast ice in the Antarctic. Pups of this species start swimming by the time they are 2 wk old, and late in lactation pups swim and dive independently of their mothers (Tedman \& Bryden 1979, Castellini et al. 1994, Burns \& Castellini 1996). Precocial swimming in this Antarctic seal is difficult to rationalise, in that they have no surface predators, but face several aquatic predators such as leopard seals Hydrurga leptonyx and killer whales. Aithough these other phocids pups do swim during the nursing period, it appears that ringed and bearded seals are the most precocial divers, and this character is likely linked to their evolutionary history with polar bears.

Weaning is generally thought to be abrupt in phocid seals, with the mother simply abandoning her pup, seemingly spontaneously. This is the case for grey, harp and hooded seals (Table 1). In these species the short lactation period simply ends with the female's departure, after which the pups fast for a period of time before going to the sea to commence self feeding. However, weaning is more gradual in bearded and ringed seals and pups start to forage for themselves while still being cared for by their mothers. This is confirmed by findings of a mixture of milk and crustaceans in stomach of pups of both of these species during late lactation (Römer \& Schaudinn 1900, Chapskii 1938, Gjertz 1983). Analyses of shapes of dives performed by ringed and bearded seal pups also indicate that they feed toward the end of lactation. This is illustrated by an increasing proportion of $\mathrm{U}$-shaped dives towards the end of lactation (Lydersen \& Hammill 1993a, Lydersen et al. 1994b). This dive profile has been suggested to indicate feeding in a number of other studies (Le Boeuf et al. 1988, Hindell et al. 1991, Schreer \& Testa 1995).

Initially, it may seem quite remarkable that these 5 North Atlantic phocid seal species, which all give birth in an ice habitat, have evolved such different behavioural strategies during the nursing period. But, viewed in a broader ecological context these various evolutionary solutions can be reconciled. A modestly complex, interrelated suite of factors including habitat stability, breeding density, access to water, body size, foraging ecology and predation pressure all appear to be influential in the patterns of behavioural ontogeny observed among the neonates of these species.

\section{PHYSICAL CHARACTERISTICS OF NEONATES AND PUP ENERGETICS}

Birth masses vary 7 - to 8 -fold within the species studied in this review. Ringed seals are the smallest species, having an average new-born body mass of $4.6 \mathrm{~kg}$ and pups of bearded seals are the largest with an average birth mass of about $34 \mathrm{~kg}$ (Table 3 ). Only the ringed seal is close to the general mammalian relationship for neonatal litter masses versus maternal body masses (log litter mass $=0.86$ maternal mass - 0.95, Kovacs \& Lavigne 1986); all of the other species fall well above the general mammalian regression line describing this relationship. Pups of Baikal and Caspian (Phoca caspica) seals display a similar ratio of pup to maternal mass at birth to ringed seals (Kovacs \& Lavigne 1986). All 3 of these species use lairs or cavities within the ice for pupping, which may compensate for their relative small size at birth by providing thermal shelter.

Phocid seal pups start to suckle quickly after birth and they grow very rapidly (Bowen 1991). This is accomplished through ingestion of large amounts of extremely energy rich milk, in addition to a very efficient conversion of milk energy into new tissue (Table 3 ). During the lactation period, pups of the 5 studied seal species gain mass at average rates between 0.4 and $5.9 \mathrm{~kg} \mathrm{~d}^{-1}$ (Table 3). Hooded seal pups double their body mass in less than $4 \mathrm{~d}$. Corresponding 'doubling' periods for bearded and ringed seals that grow slowly, relatively speaking, are 10 and $12 \mathrm{~d}$, respectively. 
Table 3. Growth and energy intake data for pups of North Atlantic, ice-breeding seals

\begin{tabular}{|c|c|c|c|c|c|c|c|}
\hline Species & $\begin{array}{l}\text { Newborn } \\
\text { mass }(\mathrm{kg})\end{array}$ & $\begin{array}{l}\% \text { of maternal } \\
\text { body mass }\end{array}$ & $\begin{array}{l}\text { Daily mass } \\
\text { gain }(\mathrm{kg})\end{array}$ & $\begin{array}{l}\text { Weaning } \\
\text { mass }(\mathrm{kg})\end{array}$ & $\begin{array}{c}\% \text { of maternal } \\
\text { body mass }\end{array}$ & $\begin{array}{c}\text { Daily milk } \\
\text { intake (MJ) }\end{array}$ & $\begin{array}{c}\text { Energy intake } \\
\text { stored as tissue }(\%)\end{array}$ \\
\hline Bearded seals & $34.0^{a}$ & 9.2 & $3.3^{t}$ & 113 & 30.6 & $154^{f}$ & $47^{1}$ \\
\hline Grey seals & $15.9^{\mathrm{b}}$ & 8.5 & $2.1^{g}$ & 47 & 25.1 & $83^{\mathfrak{g}}$ & $75^{9}$ \\
\hline Harp seals & $10.7^{c}$ & 7.7 & $2.2^{\mathrm{c}}$ & 37 & 26.8 & $80^{c}$ & $66^{c}$ \\
\hline Hooded seals & $24.3^{\mathrm{d}}$ & 10.3 & $5.9^{d}$ & 48 & 20.3 & $249^{d}$ & $73^{d}$ \\
\hline Ringed seals & $4.6^{\mathrm{e}}$ & 6.2 & $0.4^{\mathrm{h}}$ & 20 & 27.1 & $24^{1}$ & $36^{e}$ \\
\hline
\end{tabular}

The composition of pups' bodies change dramatically from the time that they are newborn until weaning. This is mainly a consequence of subcutaneous blubber deposition. Grey, harp and ringed seals are born without an insulating subcutaneous blubber layer, their body composition consists of only 3 to $6 \%$ fat (Lydersen et al. 1992a, Iverson et al. 1993, Oftedal et al. 1996). Most of this fat is an integral part of the brain tissue and is not subcutaneous blubber. But, these species are born bearing a foetal coat of white hair (Table 1). This lanugo coat is a good insulator in air when it is dry. It also increases the efficiency of solar heating, acting as a heat trap for solar energy (Øritsland 1970). However, at birth the coat is wet, and it can also become wet at other times because of rain or wet snow conditions. Under such circumstances hypothermia is avoided in very young pups through non-shivering thermogenesis, via the burning of subcutaneous brown adipose tissue (Grav \& Blix 1976). The smallest of these 3 species, the ringed seal, is born in a subnivian lair that is dug out over a breathing hole in the ice. Ringed seal pups are thus afforded some protection from harsh temperatures and winds (Smith 1976, 1980, Gjertz \& Lydersen 1986a, Lydersen \& Smith 1989, Smith et al. 1991). As lactation progresses, pups of all 3 species rapidly accumulate a layer of subcutaneous blubber. This insulating layer of fat takes over the primary role of insulation, diminishing the thermoregulatory importance of the lanugo. Simultaneously, the chemical thermoregulation that was so pronounced during the first days of life can no longer be demonstrated (Davydov \& Makarova 1965). Toward the end of lactation grey, harp and ringed seal pups start moulting their white coat. Over the next few weeks, well into the post-weaning period, they get a coat of short, coarse hair that is structurally similar to the pelts of adult seals. Retention of the white lanugo in ice-breeding species, long after its thermoregulatory role is replaced by blubber in pups, suggests that it may play a role in cryptic coloration, reducing detection by surface predators. Ringed seal pups keep their lanugo for almost 2 mo (Lydersen \& Hammill 1993a) even though it probably increases the energetic cost of swimming and diving in this aquatically precocial species. Vision is known to play an important role in the hunting behaviour of polar bears (Stirling 1974), so cryptic coloration may reduce the chance of being detected (Lydersen \& Hammill 1993a).

Neonatal bearded and hooded seals are born with subcutaneous fat; their body compositions are made up of about 10 and $14 \%$ fat, respectively (Oftedal et al. 1993, Lydersen et al. 1996). Neither species bears a full lanugo coat at birth. Bearded seals are born in a greyblue, grey-brown coat with white dorsal spots (Chapskii 1938). The presence of these white spots has lead to speculation that bearded seals are in the process of evolving cryptic coloration (Stirling 1977). It has also been suggested that the coloration of the bearded seal pups is an adaptation to avoid aquatic predators, such as walruses or killer whales (Burns 1967). However, it is also possible that it may simply reflect an evolutionary link to the tropical monachines (McLaren 1975) that give birth to dark coloured pups (Kenyon 1981). This phylogenetic picture of bearded seal evolution is supported by recent genetic work by Perry et al. (1995). Much of the foetal hair of bearded seal pups is moulted in utero (Kovacs et al. 1996). The foetal hairs that remain attached to bearded seal pups at birth are a little lighter in colour than the shorter permanent hairs (Kovacs et al. 1996). The remaining lanugo is gradually shed, so the pups are completely moulted before weaning occurs (Kovacs et al. 1996). Hooded seals are born completely moulted of their lanugo. At birth they bear a grey-blue, short, coarse pelage (Shepeleva 1973). The coloration of these pups, in concert with the sexual dimorphism in adults and secondary display organs in adult males (Berland 1965) has lead to speculation that this species had a non-aquatic mating system without surface predators in earlier times (Stirling 1983).

Both bearded and hooded seal pups are born with a subcutaneous layer of blubber which is considered to 
be an adaptation to entering the water shortly after birth (Oftedal et al, 1991, Lydersen et al. 1996). Bearded seal pups normally enter the water within hours of being born (Kovacs et al. 1996), and quickly develop swimming and diving skills (Hammill et al. 1994, Lydersen et al. 1994b). However, these physical and behavioural features are not necessarily adaptations to breeding on ice. Another phocid seal species, the harbour seal, also gives birth to pups that moult in utero and possess a subcutaneous blubber layer as newborns (Oftedal et al. 1991). Harbour seal pups also normally enter the water during their first day of life, often at the first high tide following their birth (Scheffer \& Slipp 1944, Venables \& Venables 1955, Renouf et al. 1983). Hooded seal pups do not enter the water until after weaning, even though they are born with features that can be interpreted as adaptations to an early aquatic debut (Oftedal et al. 1991). However, the hooded seal lactation period is only $4 \mathrm{~d}$ long (Bowen et al. 1985), so even a post-nursing entry to the water can occur at a very young chronological age. Additionally, in this species prenatal energy deposition is likely essential in order to accomplish delivery of sufficient energy to the pups prior to weaning (Oftedal et al. 1993, Lydersen et al. 1997). Hooded seal pups have the highest energy content of any newborn mammal (Oftedal et al. 1993).

Fat content of the pups at weaning varies between 40 and $47 \%$ for grey, harp, hooded and ringed seals (Lydersen \& Hammill 1993b, Oftedal et al. 1993, 1996 , Lydersen et al. 1995, 1997). Bearded seal have a fat content of only $25 \%$ at weaning (Lydersen et al. 1996). This low fat content is probably because of their very active, aquatic lifestyle. This is in marked contrast to grey, harp and hooded seal pups which spend the whole nursing period on the ice and are abruptly weaned, as discussed earlier. The huge blubber deposits in these pups at weaning have an obvious thermoregulatory role. But, they also must be considered as energy stores that fuel the pups while they complete the post-weaning moult and the period when they learn to swim, dive and capture food. Bearded and ringed seal pups are capable of all of these sorts of activities at weaning, and therefore would not need to have this sort of fat reserve. Large blubber deposits might even be a disadvantage for these pups, since the extra buoyancy might increase their energy expenditure in connection with diving. This explanation fits well with the bearded seals, which are weaned with a body fat content that is similar to that of adults (Ryg et al. 1990a). However, the situation for ringed seal pups is different. It may be that the small size of ringed seal pups necessitates relatively more blubber to stay thermoneutral, compared with the other, larger pups, due to an unfavourable surface-to-volume ratio. Ringed seals are small seals also as adults, and fat contents of
$40 \%$ (as found in the pups) are not uncommon in sexually mature specimens (Ryg et al. 1990b). The relatively high fat content in ringed seal pups does not seem to put much extra strain on their energy consumption during diving. They seem to be very capable divers (Lydersen \& Hammill 1993a), and even though they have a fat content of $40 \%$ and a coat of long white hair their field metabolic rate (FMR) is among the lowest of all the seal pups studied in this review (Table 4).

The daily energy intake in pups of the 5 species studied varied 10 -fold. The lowest values of $24 \mathrm{MJ}$ was recorded for ringed seals and the highest, $249 \mathrm{MJ}$, was for hooded seals (Table 3). The latter is accomplished through a daily ingestion of more than $10 \mathrm{l}$ of milk that has an average fat content of about $60 \%$ (Lydersen et al. 1997). If we consider how much of the ingested energy is stored as new tissue in the various species, grey, harp and hooded seals are found to store as much as 66 to $75 \%$ of the energy ingested. Corresponding figures for bearded and ringed seals are 47 and $36 \%$, respectively (Table 3 ). These values basically reflect the general behavioural patterns of the different seal pups.

The FMR of the pups of the 5 species studied (Tabie 4), varied between 0.53 and $0.71 \mathrm{MJ} \mathrm{kg}^{-1} \mathrm{~d}^{-1}$ or between 3.8 and 6.0 times the basal metabolic rate (BMR) (Table 4). (The use of the BMR in this context is somewhat improper since a number of the standard conditions [Kleiber 1975] for measuring the BMR are not fulfilled in free-living pups, but it is useful in a comparative context.) At first glance, the FMR measurements seem to contradict the reasoning in several parts of the discussion above (Table 4). For example, the active bearded seal pups have an FMR that in terms of multiples of BMR is very similar to that of the sedentary hooded seal pups. A possible reason for the surprisingly high FMR in hooded seal pups may be the rate at which they accumulate blubber. Hooded seal pups deposit $4.5 \mathrm{~kg}$ of their $5.9 \mathrm{~kg}$ daily mass gain as fat

Table 4. Field metabolic rates of nursing pups of North Atlantic, ice-breeding seals

\begin{tabular}{|lcc|}
\hline Species & $\begin{array}{c}\text { Field metabolic rate } \\
\left(\mathrm{MJ} \mathrm{kg}^{-1} \mathrm{~d}^{-1}\right)\end{array}$ & $\begin{array}{c}\text { Multiples of basal } \\
\text { metabolic rate }\end{array}$ \\
\hline Bearded seals & $0.64 \pm 0.07^{\mathrm{a}}$ & $6.0 \pm 0.5^{\mathrm{a}}$ \\
Grey seals & $0.55 \pm 0.13^{\mathrm{b}}$ & $4.5 \pm 0.9^{\mathrm{b}}$ \\
Harp seals & $0.53 \pm 0.06^{\mathrm{c}}$ & $3.9 \pm 0.4^{\mathrm{c}}$ \\
Hooded seals & $0.71 \pm 0.13^{\mathrm{d}}$ & $5.8 \pm 1.1^{\mathrm{d}}$ \\
Ringed seals & $0.55 \pm 0.10^{\mathrm{e}}$ & $3.8 \pm 0.6^{\mathrm{e}}$ \\
a Lydersen et al. (1996), ${ }^{\mathrm{b}}$ Lydersen et al. (1995), ${ }^{\mathrm{C}}$ Lydersen \\
\& Kovacs (1996), ${ }^{\mathrm{d}}$ Lydersen et al. (1997), ${ }^{\mathrm{C}}$ Lydersen \& \\
\hline
\end{tabular}


(Lydersen et al. 1997). If we consider the process of creating blubber, about $7 \%$ of the energy of the transferred fat is lost, mostly as heat, during its transition from dietary fat (Flatt 1978). This means that the daily fat creation in hooded seals takes $12.4 \mathrm{MJ}$ of energy, which represents an increase in the FMR of these pups by a value corresponding to 3 times the BMR (Lydersen et al. 1997). If we do the same type of calculations for ringed and harp seals, the deposition of fat would account for an increase in FMR of only 0.3 and 1.1 times the BMR, respectively (Lydersen et al. 1997). Several assumptions are made when performing such calculations. The $7 \%$ energy loss in depositing blubber may be an overestimate of the cost to hooded seals due to the very similar fatty acid compositions of milk and blubber for this seal (Iverson et al. 1995). However, the cost of protein deposition would increase the value further, so the relative values when doing interspecific comparisons would probably be in the order of magnitude shown here. The calculations suggest that significant amounts of energy are involved in the growth process when it occurs at the extreme rates seen in hooded seals. Growing involves substantial amounts of energy lost as heat, and it has been documented that sedentary, nursing hooded seal pups have a significantly higher body temperature than when they are weaned and more active (Lydersen et al. 1997). If we consider the fraction of the received energy that has to be allocated to cover the FMR in hooded seals, it represents a very low value compared with the other seal species. Only $9.5 \%$ of the received milk energy is allocated to pup metabolism in hooded seals. Corresponding values for bearded, grey, harp and ringed seal pups are $28.6,29.9,14.6$ and $41.4 \%$, respectively (Lydersen et al. 1997). So hooded seals have a relatively high FMR during the nursing period, but use a very small fraction of their extremely high energy intake to cover these costs. Most of the received energy is therefore available for storage.

\section{MATERNAL BEHAVIOUR}

Parental care in pinnipeds is exclusively the task of females (Kovacs \& Lavigne 1986, Oftedal et al. 1987, Trillmich 1996), as is the case for more than $95 \%$ of mammalian species (Clutton-Brock 1991). Maternal care in seals consists primarily of milk transfer from the mother to the offspring, but also includes defence of the neonate against conspecifics, and other animals in some species.

The process of giving birth seems to be a rapid event in most pinnipeds (Bowen 1991). In harp, hooded and grey seals, pup delivery occurs in minutes or even seconds (Stewart et al. 1981, Frank et al. 1985, Bowen
1991). The umbilical cord is broken during delivery or when the mother turns to investigate and sniff her pup. The placenta is eaten by scavenging birds or is simply left on the ice. Bearded seals births are also rapid (Kovacs et al. 1996). Bearded seal mother-pup pairs move away from the birth floe shortly after birth. Ringed seals, that pup in lairs, have never been observed while giving birth, but it is known that mothers remove the placenta from the lair. Presumably, bearded seals and ringed seals remove signs of birth or move their pups in order to reduce olfactory clues for predators (Stirling 1977).

The females of the 5 species in this review spend highly variable fractions of their time during the lactation period on the ice surface. Bearded and ringed seal mothers haul out less than $20 \%$ of the time. The most extreme case at the other end of the scale are hooded seal mothers, which spend the entire lactation period on the ice with the pup (Table 5). Maternal behaviour while on the ice consists largely of time spent idle or sleeping in between sessions of nursing among the species studied thus far (Kovacs 1987a, Haller et al. 1996, Holsvik 1998). Based on data from TDRs or direct observations, the number of nursing sessions per day for the 5 species varies between 3 and 58 (Table 2). The ringed seal has the fewest number, while the hooded seal has the greatest (Perry \& Stenson 1992, Lydersen \& Hammill 1993a, Lydersen et al, 1994b, Haller et al. 1996, Lydersen \& Kovacs 1996). Bearded seal females spend $84 \%$ of their time during the nursing period in the water (Table 5). This value is derived from data on pup activity budgets (Lydersen et al. 1994b) and direct observations of mother-pup behaviour (Holsvik 1998). The former, remotely sampled data can be used to interpret maternal behaviour because mothers usually accompany their pups when they are swimming and diving. Additional studies, based on TDRs, satellitelinked TDRs and direct observations (Gjertz et al. 1995, Holsvik 1998, Kovacs et al. unpubl. data) also

Table 5. Activity budgets of lactating females of North Atlantic, ice-breeding seals

\begin{tabular}{|c|c|c|c|}
\hline Species & $\begin{array}{l}\text { Hauled out } \\
\qquad \%)\end{array}$ & $\begin{array}{c}\text { At surface } \\
\qquad \%)\end{array}$ & $\begin{array}{c}\text { Diving } \\
(\%)\end{array}$ \\
\hline Bearded seals & $16^{\mathrm{u}}$ & \multicolumn{2}{|c|}{ Total time in water: $84 \%$} \\
\hline Grey seals & $72^{\mathrm{b}}$ & $20^{\mathrm{b}}$ & $8^{b}$ \\
\hline Harp seals & $29^{c}$ & $24^{c}$ & $47^{c}$ \\
\hline Hooded seals & $100^{d}$ & $0^{d}$ & $0^{d}$ \\
\hline Ringed seals & $18^{\mathrm{e}}$ & \multicolumn{2}{|c|}{ Total time in water: $82 \%$} \\
\hline \multicolumn{4}{|c|}{$\begin{array}{l}\text { a'Lydersen et al. (1994b), in combination with Holsvik } \\
\text { (1998), bLydersen et al. (1994a), }{ }^{c} \text { Lydersen \& Kovacs } \\
\text { (1996), }{ }^{d} \text { Kovacs \& Lavigne (1992), }{ }^{e} \text { Lydersen (1995) }\end{array}$} \\
\hline
\end{tabular}


show that bearded seal mothers are very active divers during lactation. They undertake long bouts of diving with many U-shaped dives that suggest that feeding is taking place. The longest dive duration recorded for bearded seals to date is $25 \mathrm{~min}$ and the greatest depth recorded is $250 \mathrm{~m}$ (Gjertz et al. 1995), but diving during the lactation period is usually shallow and of short duration

Ice-breeding grey seal mothers show a lot of intraspecific variation in the fraction of time spent in the water during lactation. The average time spent in the water during a study by Lydersen et al. (1994a) was $28 \%$ (Table 5 ), but the range among individuals was 0.4 to $55.2 \%$. There might be several explanations for this variation. One factor is the variability in ice topography within the breeding habitat. Some ice-breeding female grey seals have easy access to open water while others do not. Ridging caused by movements of the ice restricts some females from getting to the water. Other females nurse their pups at the edges of open cracks or breathing holes and they spent considerably more time in the water (Lydersen et al. 1994a, Haller et al. 1996). Dives recorded for lactating grey seals were shallow and of short duration (mean 110 s) (Lydersen et al. 1994a), but this may be due in part to the shallow water in the study area.

Harp seal females spend between 70 and $80 \%$ of their time in the water (Lydersen \& Kovacs 1993, 1996). A large fraction of this time (33 to $43 \%$ ) is spent at the surface. Most of the remaining time in the water is spent diving, to the bottom of the study area in some cases (90 to $100 \mathrm{~m}$ depth). The $\mathrm{U}$-shaped profile of many of the dives suggests feeding may take place, and the overall energy budgets of some females confirms this suggestion (Lydersen \& Kovacs 1993, 1996). The longest dive recorded for a lactating harp seal mother was $13 \mathrm{~min}$. Only $0.6 \%$ of all recorded dives exceeded this species' theoretical aerobic dive limit (ADL) (Lydersen et al. 1992b). Again, this may be due to the relatively shallow water in the study area.

A single $17 \mathrm{~d}$ long TDR record for a lactating ringed seal documented that she spent $82 \%$ of her time in the water (Table 5). Another study, again of a single female during the nursing period found that she spent only $55 \%$ of her time in the water (Lydersen 1991). However, the latter study might have included time after the female had weaned her pup (pup mass $22 \mathrm{~kg}$ at first capture) and is therefore excluded from the activity budget in Table 5 . The seals in both these studies dove to the bottom of the study area (about $90 \mathrm{~m}$ ). The maximum recorded dive duration was $21.3 \mathrm{~min}$, which is about 3 times the theoretical ADL for adult ringed seals and close to their estimated maximum breathhold capacity (Lydersen et al. 1992b). A comprehensive study of ringed seal diving, including some diving by lactating females, was conducted in Canadian waters by Kelly \& Wartzok (1996). In this study, 3 lactating females all had median dive durations between 6.2 and $8.1 \mathrm{~min}$. Maximum depth and duration reported by these authors were $186 \mathrm{~m}$ and 26.4 min. These 3 ringed seal mothers also performed long dive bouts with $U$-shaped dives that again suggest that they were feeding.

Females of the different species may spend time in the water for various reasons. Although foraging is likely reduced during lactation in most phocids, 4 of the 5 species studied in this review do some feeding during lactation. For some of these seal species feeding is essential in order to obtain enough energy to complete lactation (see below). Only the hooded seal, which remains at the ice-surface throughout lactation, fasts entirely. Another reason for aquatic periods may be to avoid detection by surface predators. The presence of a large adult body is easy to detect on the ice surface, whereas immobile pups can be quite cryptic. A third contributing factor might be avoidance of harsh environmental conditions. For grey seal females a significant negative correlation was found between haul-out frequency and increasing wind-chill (Lydersen et al. 1994a). Surface temperatures below $-20^{\circ} \mathrm{C}$ and wind speed above $10 \mathrm{~m}$ $\mathrm{s}^{-1}$ were experienced during the breeding season of these seals. If hauled out during such conditions, the seals would probably have to increase the blood circulation to the skin to avoid having it freeze and therefore they would have to increase their metabolism. Temperatures are always above $-1.9^{\circ} \mathrm{C}$ in the water and the effective insulation from the subcutaneous blubber layer prevents the need to increase metabolic rates in order to stay thermoneutral in this medium. Additionally, mating and other social activities take place principally in the water during the breeding season.

\section{MATERNAL ENERGETICS}

The average body masses of the mothers at parturition for the 5 study species varied from about $70 \mathrm{~kg}$ in ringed seals to about $370 \mathrm{~kg}$ in bearded seals (Table 6). During the nursing period the mothers of the 5 different species lose body mass at rates between 0.65 to $10.1 \mathrm{~kg} \mathrm{~d}^{-1}$ (Table 6). It has generally been thought that phocids cover all the energy expenses during lactation from maternal energy deposits, however, this appears to be valid only for a few of the largest species within this group, like southern Mirounga leonina and northern elephant Mirounga angustirostris seals, hooded seals, and grey seals in some areas (Fedak \& Anderson 1982, Kretzmann et al. 1993, Fedak et al. 1996). In the 
Table 6. Maternal body mass data during the nursing period in North Atlantic, ice-breeding seals

\begin{tabular}{|c|c|c|c|}
\hline Species & $\begin{array}{l}\text { Maternal mass } \\
\text { at parturition }(\mathrm{kg})\end{array}$ & $\begin{array}{c}\text { Daily mass } \\
\text { loss }(\mathrm{kg})\end{array}$ & $\begin{array}{c}\text { Feeding during } \\
\text { nursing period }\end{array}$ \\
\hline Bearded seals & $369^{i}$ & $4.4^{\prime \prime}$ & Yes $^{g}$ \\
\hline Grey seals & $187.3^{i}$ & $5.1^{b}$ & Some $e^{b}$ \\
\hline Harp seals & $138.2^{\mathrm{c}}$ & $3.1^{c}$ & Some $e^{c}$ \\
\hline Hooded seals & $237^{d}$ & $10.1^{\mathrm{d}}$ & $\mathrm{No}^{\mathrm{d}}$ \\
\hline Ringed seals & $73.7^{e}$ & $0.65^{i}$ & Yes $^{i}$ \\
\hline \multicolumn{4}{|c|}{ 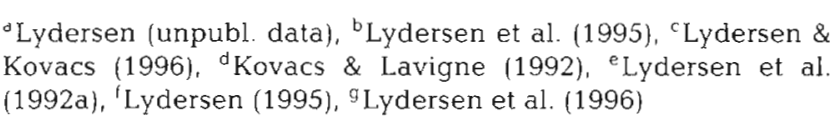 } \\
\hline
\end{tabular}

studies presented in this review, the only species in which the mothers spent all the nursing period on the ice was hooded seals (Table 5). Thus, they clearly covered all the expenses related to lactation from their own energy stores which are mainly located in the subcutaneous blubber, but some feeding took place among females of all of the other species.

Mass transfer rates have often been used as an index of how efficiently energy is transformed from maternal tissue to pup tissue (Costa et al. 1986, Kovacs et al. 1991. Kovacs \& Lavigne 1992, Haller et al. 1996, Arnbom et al. 1997). However, this is only accurate in cases where females do not feed during the lactation period. The mass transfer rate found for hooded seals in the present study was $58 \%$, which is in close accordance with the only other longitudinal study of this parameter for hooded seals $(63 \%$, Kovacs \& Lavigne 1992). Mothers of both grey and harp seals seem to have enough energy stored in their blubber to complete lactation without requiring extra food intake. Indeed, some mothers of these species spend almost the entire lactation period on the ice attending pups which have normal growth rates (Lydersen \& Kovacs 1993, 1996, Lydersen et al. 1994a, 1995). However, based on mass loss records and TDR data, some mothers of these species feed during this period, and some do so at considerable rates (Lydersen et al. 1994a, Lydersen \& Kovacs 1996). Since the mothers of grey and harp seals spend 30 and $70 \%$ of their time, respectively, in the water swimming and diving (Table 5) it would be strange if they did not take advantage of prey organisms that were present in the nursing area. Evidently the females do at least feed opportunistically. Harp seals show a significant negative correlation between time spent in the water and maternal mass loss during lactation (Lydersen \& Kovacs 1996).

Based on mass loss of mothers and gain in pups, in combination with data on pup energetics and milk energy intake, ringed and bearded seal mothers are found to feed significantly during the nursing period (Lydersen \& Hammill 1993b, Lydersen 1995, Lydersen et al. 1996). Bearded seal females spend about $80 \%$ of the lactation period in the water. Some of this time is spent at the surface attending the pup, but the rest of the time is spent swimming and diving. During lactation they move around over large distances, mainly in shallow coastal areas (Table 5, Hammill et al. 1994, Gjertz et al. 1995). Thus, they remain in their normal benthic feeding grounds. Ringed seal mothers need a daily food intake corresponding to at least $2 \mathrm{~kg}$ of polar cod Borogadus saida or $3 \mathrm{~kg}$ of Themisto libellula (which are the most common prey for this seal in the study area) (Gjertz \& Lydersen 1986b) during the lactation period in order to balance their daily energy budgets (Lydersen 1995). Since ringed seals usually give birth in the fast ice, food availability is likely a very important determinant for the sizes of their territories, and may also be an explanation for why closely situated areas can have very different densities of breeding females (Lydersen et al. 1990, Lydersen \& Ryg 1991).

The tremendous growth rates in the pups of the species studied in this review (Table 3), and in phocid seals in general, are accomplished through high daily intakes of extremely-energy-rich milk. Females of species with short lactation periods would be expected to produce milk with a higher fat content in order to deliver equivalent amounts of energy during a shorter period of time (Costa 1991). This prediction is in agreement with results of the present review. Grey, harp and hooded seals, which have the shortest lactation periods, all produce milk with fat contents above $60 \%$ (Lydersen et al. 1995, 1997, Lydersen \& Kovacs 1996). The highest record among them is found in hooded seals (68.1\%, Lydersen et al. 1997) and this species has the shortest lactation period. In fact, this species produces the most-energy-rich milk among all mammals and holds the record for brevity of nursing (Oftedal et al. 1988).

Milk composition varies a lot through the lactation period for many phocid seals. The normal pattern is that the fat content is initially low and the water content is high. Then, as lactation proceeds, the fat content increases while the water content decreases (Oftedal et al. 1987). The reason for this general pattern is that mothers substitute milk fat for water in order to maintain their water balance during this energy-draining period, when they acquire little if any water from their food because they reduce food intake or fast (Kooyman \& Drabek 1968, Riedman \& Ortiz 1979). Grey seals and harp seals display this typical pattern (Fig. 1). Early in lactation the milk of these 2 species is below $40 \%$ fat, but it increases to over $60 \%$ fat by the end of the lactation period (Lydersen et al. 1995, Lydersen \& Kovacs 1996). Hooded seals are somewhat exceptional, in that 
their milk has a high stable fat content throughout lactation. The extreme brevity of the lactation period probably means that females of this species do not face water stress during lactation. Milk of bearded seals and ringed seals contains less fat than in greys, harps or hoods and the fat content changes only slightly during the course of the lactation period (Fig. 1). These mothers feed quite a lot during lactation, so they do not experience strain on their water balance during lactation in the manner that fasting or food-reduced mothers do. Thus, they can produce a reasonably fat-rich milk with a relatively constant composition throughout the whole nursing period.

Milk energy output is by far the largest component of the energetic costs for phocids to produce a weaned pup (Table 7). These net maternal investment values are derived by multiplying daily milk intake (Table 3 ) by the duration of lactation for the respective species (Table 1). Hooded seals in this study had a lactation period of $3.1 \mathrm{~d}$, which was used in the calculation of values provided in Table 7 . Other studies of this species suggest that the duration of lactation is slightly longer (4 d, Bowen et al. 1985; 3.8 d, Kovacs \& Lavigne 1992). However, even using the shorter duration, the milk energy output (772 MJ) estimated in this study was a little higher than in the only other available energetics study of lactation in hooded seals (746 MJ, Oftedal et al. 1993).

In addition to the cost of lactation, maternal investment also includes the production of the foetus and placenta, and the energy to maintain the metabolic requirements of the foetus during pregnancy (Table 7). The latter parameter is referred to as the heat of gestation. A relationship derived for terrestrial mammals (Brody 1945) was used to calculate this parameter for the various seal species under study. The heat of gestation was defined as $Q_{\mathrm{g}}=18.4 \mathrm{BM}^{1.2}$, where $Q_{\mathrm{g}}$ is the
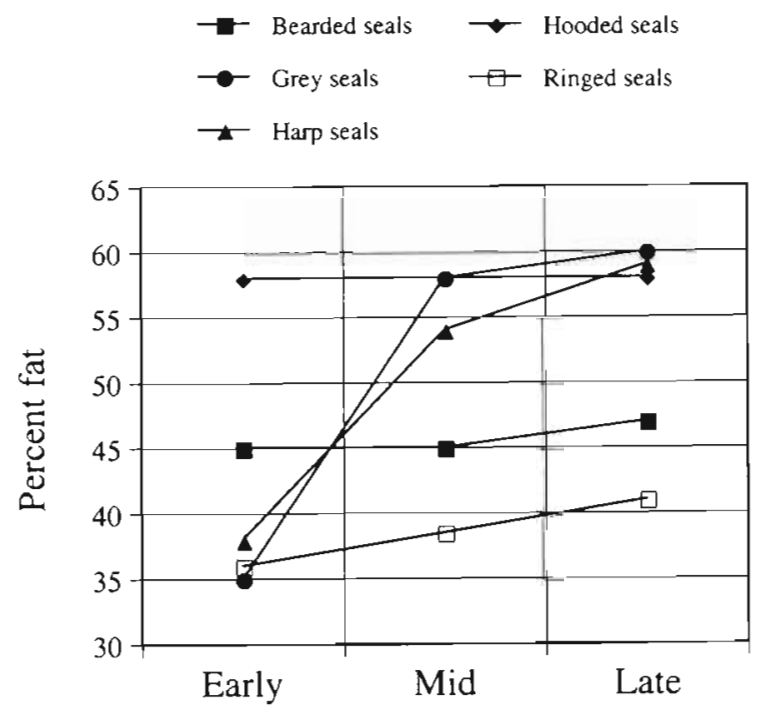

Fig. 1. Change in milk fat content during the progress of lactation in ice-breeding North Atlantic phocid seals

heat of gestation (MJ) and BM is the body mass of the newborn in $\mathrm{kg}$ (Brody 1945). When combining these different components of the maternal energy budgets, the net maternal investment for the seal species studied ranged between 1075 and 5283 MJ (Table 7). This great variation is mainly a consequence of the size difference among the study species (Fig. 2).

When considering the different components of maternal investment (Table 7), hooded seals have the lowest milk energy output independent of body mass. The hooded seal neonate is about 6 times larger than the ringed seal pup, and the hooded seal mother is more than 3 times larger than ringed seal mothers. However, despite these size differences, the gross milk energy output for hooded seals is smaller than for ringed seals. The short duration of nursing in

Table 7. Net maternal investment involved in producing a weaned pup for North Atlantic, ice-breeding seals. Total milk energy output is derived by multiplying the duration of lactation (Table 1) with daily milk energy intake (Table 3 ) for each species

\begin{tabular}{|c|c|c|c|c|c|}
\hline Species & $\begin{array}{c}\text { Total milk } \\
\text { energy output (MJ) }\end{array}$ & $\begin{array}{l}\text { Energy content } \\
\text { of newborn (MJ) }\end{array}$ & $\begin{array}{l}\text { Energy content } \\
\text { of placenta }(\mathrm{MJ})\end{array}$ & $\begin{array}{c}\text { Heat of } \\
\text { gestation' (MJ) }\end{array}$ & $\begin{array}{c}\text { Maternal } \\
\text { investment (MJ) }\end{array}$ \\
\hline Bearded seals & 3696 & $298.5^{a}$ & $22.0^{f}$ & 1266 & 5283 \\
\hline Grey seals & 1239.0 & $89.5^{b}$ & $9.2^{9}$ & 509 & 1847 \\
\hline Harp seals & 954.0 & $73.7^{c}$ & $5.9^{h}$ & 316 & 1350 \\
\hline Hooded seals & 771.9 & $245.4^{\mathrm{d}}$ & $15.2^{\prime}$ & 846 & 1879 \\
\hline Ringed seals & 932.1 & $26.3^{e}$ & $1.3^{e}$ & 115 & 1075 \\
\hline \multicolumn{6}{|c|}{ 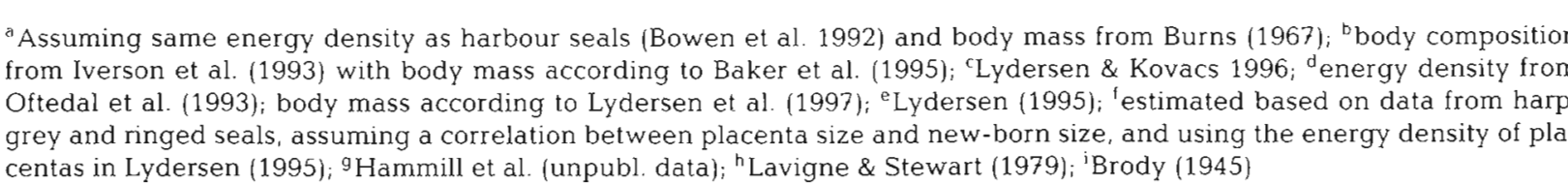 } \\
\hline
\end{tabular}




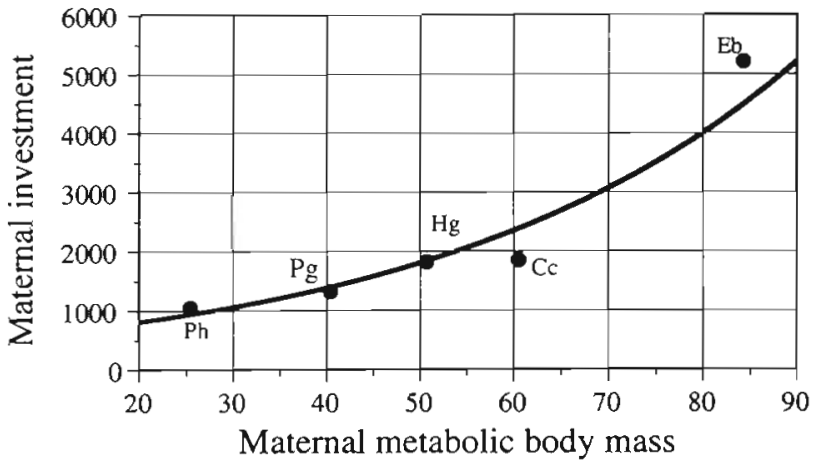

Fig. 2. Net maternal investment (MJ) in relation to maternal metabolic body mass $\left(\mathrm{BM}^{0.75}\right)$ in ice-breeding North Atlantic phocid seals. Eb: bearded seal, $\mathrm{Hg}$ : grey seal, Pg: harp seal, Cc: hooded seal, Ph: ringed seal

hooded seals dramatically reduces the energy used to maintain maternal metabolism, the so-called 'metabolic overhead' costs (Fedak \& Anderson 1982). This is a marked advantage for females that fast during the nursing period. So why have all the other phocids not evolved towards a shorter and more intense lactation period if this is energetically profitable? The extremes seen in hooded seal nursing may be unachievable by other species due to various combination of factors such as maternal body size and energy storage ability, physiological limitations to trans-placental fat transfer, inability of mothers to tolerate fasting stress, and the need to avoid neonatal predation, or possibly factors such as food availability for neonates during the period of early nutritional independence play a role.

\section{GENERAL CONCLUSIONS}

This study has demonstrated a variety of behavioural and energetic aspects of the lactation period in 5 different species of ice-breeding seals. In very broad terms, it suggests that the term 'ice-breeding' is too simplistic and may lead to misconceptions about the actual degree of variability that occurs in the breeding habitats of the species studied. The variation is actually quite remarkable in terms of: temporal and structural stability of the pupping platform; the degree to which animals have access to the water; the risk of predation; and perhaps also the local availability of food. These factors all appear to influence the behaviour and allocation of energy during the lactation period of the species studied. Mainly as a consequence of variation in these variables, 2 basically different nursing strategies have evolved. The pattern displayed by grey, harp and hooded seals involves a short lactation period, during which a large amount of energy is transferred from the mother to the pup through extremely energy-rich milk. Pups are generally very inactive and consequently a very high proportion of the received energy can be stored as body tissue mainly in the form of subcutaneous blubber. The mothers generally feed little or not at all during the nursing period and the pups are weaned abruptly, having not yet entered the water. The other strategy, which is found in bearded and ringed seals involves a longer lactation period, where less-energy-rich milk is transferred to very active pups. These pups learn to swim and dive during the nursing period, and are weaned with body compositions that are similar to the adults. The mothers feed during lactation and weaning is less abrupt, with pups feeding independently, while still receiving milk from their mothers.

\section{LITERATURE CITED}

Arnason U, Widegren B (1986) Pinniped phylogeny enlightened by molecular hybridizations using highly repetitive DNA. Mol Biol Evol 3:356-365

Arnbom T, Fedak MA, Boyd IL (1997) Factors affecting maternal expenditure in southern elephant seals during lactation. Ecology 78:471-483

Baker SR, Barette C, Hammill MO (1995) Mass transfer during lactation of an ice-breeding pinniped, the grey seal (Halichoerus grypus), in Nova Scotia, Canada. J Zool Lond 236:531-542

Barnes LG, Domning DP, Ray CE (1985) Status of studies on fossil marine mammals. Mar Mammal Sci 1:15-53

Bartholomew GA (1970) A model for the evolution of pinniped polygyny. Evolution 24:546-559

Bedard C (1993) Reproductive behaviour of grey seals (Halichoerus grypus) breeding on the seasonal pack-ice, Gulf of St. Lawrence, Canada. MSc thesis, University of Waterloo, Waterloo, ONT

Berland B (1965) The hood and its extrusible balloon in the hooded seal-Cystophora cristata Erxl. Norsk Polarinst Årbok 1965:95-102

Berta A, Ray CE, Wyss AR (1989) Skeleton of the oldest known pinniped, Enaliarctos mealsi. Science 244:60-62

Boness DJ, Bowen WD, Oftedal OT (1988) Evidence of polygny from spatial patterns of hooded seals. Can J Zool 66:703-706

Boness DJ, Bowen WD, Oftedal OT (1994) Evidence of a maternal foraging cycle resembling that of otariid seals in a small phocid, the harbour seal. Behav Ecol Sociobiol 34: 95-104

Bonner WN (1984) Lactation strategies in pinnipeds. Problems for a marine mammalian group. Symp Zool Soc Lond 51:253-272

Bonner WN (1989) The natural history of seals. Christopher Helm Ltd, London

Bowen WD (1991) Behavioural ecology of pinniped neonates. In: Renouf D (ed) The behaviour of pinnipeds. Chapman and Hall, London, p 66-127

Bowen WD, Oftedal OT, Boness DJ (1985) Birth to weaning in 4 days: remarkable growth in the hooded seal, Cystophora cristata. Can J Zool 63:2841-2846

Bowen WD, Boness DJ, Oftedal OT (1987) Mass transfer from mother to pup and subsequent mass loss by the weaned 
pup in the hooded seal, Cystophora cristata. Can J Zool 65: $1-8$

Bowen WD, Oftedal OT, Boness DJ (1992) Mass and energy transfer during lactation in a small phocid, the harbor seal (Phoca vitulina). Physiol Zool 65:844-866

Brody S (1945) Bioenergetics and growth with special reference to the efficiency complex in domestic animals. Reinhold Publ, New York

Burns JJ (1967) The Pacific bearded seal. Alaska Dept Fish Game, Juneau, AK

Burns JM, Castellini MA (1996) Physiological and behavioural determinants of the aerobic dive limit in Weddell seal (Leptonychotes weddelli) pups. J Comp Physiol B 166:473-483

Castellini MA, Testa JW, Rea LD, Moss JM, Hastings KK (1994) Diving development and survivorship in Weddell seal pups. Antarct J 29:171-172

Chapskii KK (1938) The bearded seal (Erignathus barbatus, Fabr.) of the Kara and Barents Seas. Can Fish Mar Serv Transl Ser No. 3162:1-145

Clutton-Brock TH (1991) The evolution of parental care. Princeton Univ Press, Princeton, NJ

Costa DP (1991) Reproductive and foraging energetics of pinnipeds: implications for life history patterns. In: Renouf $D$ (ed) The behaviour of pinnipeds. Chapman and Hall, London, p 300-344

Costa DP, LeBoeuf BJ, Huntley AC, Ortiz CL (1986) The energetics of lactation in the northern elephant seal, Mirounga angustirostris. J Zool Lond 209:21-33

Davydov AF, Makarova AR (1965) Changes in heat regulation and circulation in newborn seals on transition to aquatic form of life. Proc Fed Am Soc Exper Biol 24:563-566

de Muizon C (1982) Phocid phylogeny and dispersal. Ann S Afr Mus 89:176-213

Fedak MA, Anderson SS (1982) The energetics of lactation: accurate measurements from a large wild mammal, the grey seal (Halichoerus grypus). J Zool Lond 198:473-479

Fedak MA, Arnbom T, Boyd IL (1996) The relation between the size of elephant seal mothers, the growth of their pups, and the use of maternal energy, fat, and protein during lactation. Physiol Zool 69:887-911

Flatt JP (1978) The biochemistry of energy expenditure. In: Bray GA (ed) Recent advances in obesity research. Newman, New York, p 211-228

Frank RJ, Ronald K, Lightfoot N (1985) Parturition in the hooded seal, Cystophora cristata (Erxleben). J Mammal 66:558-559

Furgal CM, Innes S, Kovacs KM (1996) Characteristics of ringed seal, Phoca hispida, subnivean structures and breeding habitat and their effects on predation. Can $\mathrm{J}$ Zool 74:858-874

Gazo M, Cappozzo HL (1996) Diving behaviour and transition to weaning in Mediterranean monk seal (Monachus monachus) pups on the Cabo Blanco Peninsula, western Sahara. Monachus News (1996) 2:8

Gentry RL, Kooyman GL (eds) (1986) Fur seals - maternal strategies on land and at sea. Princeton Univ Press, Princeton, NJ

Gjertz I (1983) Ernæring og kondisjonsforhold hos ringsel (Phoca hispida Schreber, 1775) i Spitsbergenområdet. Cand real thesis Inst Biol, Univ Oslo

Gjertz I, Lydersen C (1986a) Polar bear predation on ringed seals in the fast-ice of Hornsund, Svalbard. Polar Res 4: $65-68$

Gjertz I, Lydersen C (1986b) The ringed seal (Phoca hispida) spring diet in northwestern Spitsbergen. Polar Res 4: $53-56$
Gjertz I, Kovacs KM, Lydersen C, Wiig $\varnothing$ (1995) Satellite tracking of bearded seals from Svalbard. In: 11th Bien Conf Biol Mar Mammals, Orlando, FL Dec 14-18, 1995, p 44

Grav HJ, Blix AS (1976) Brown adipose tissue - a factor in the survival of harp seal pups. Can J Physiol Pharmacol 54: $409-412$

Haller MA, Kovacs KM, Hammill MO (1996) Maternal behaviour and energy investment by grey seals (Halichoerus grypus) breeding on land-fast ice. Can $\mathrm{J}$ Zool 74: $1531-1541$

Hammill MO, Smith TG (1990) Application of removal sampling to estimate the density of ringed seals (Phoca hispida) in Barrow Strait, Northwest Territories. Can J Fish Aquat Sci 47:244-250

Hammill MO, Lydersen C, Ryg M, Smith TG (1991) Lactation in the ringed seal (Phoca hispida). Can J Fish Aquat Sci 48: $2471-2476$

Hammill MO, Kovacs KM, Lydersen C (1994) Local movements by nursing bearded seal (Erignathus barbatus) pups in Kongsfjorden, Svalbard. Polar Biol 14:569-570

Hindell MA, Slip DJ, Burton HR (1991) The diving behaviour of adult male and female southern elephant seals, Mirounga leonina (Pinnipedia: Phocidae). Aust J Zool 39: 595-619

Holsvik R (1998) Maternal behaviour and early behavioural ontogeny of bearded seals (Erignathus barbatus) from Svalbard, Norway. Cand sci thesis, Norw Univ Sci Technol NTNU, Trondheim

Iverson SJ, Bowen WD, Boness DJ, Oftedal OT (1993) The effect of maternal size and milk energy output on pup growth in grey seals (Halichoerus grypus). Physiol Zool 66:61-88

Iverson SJ, Oftedal OT, Bowen WD, Boness DJ, Sampugna J (1995) Prenatal and postnatal transfer of fatty acids from mother to pup in the hooded seal. J Comp Physiol B 165: $1-12$

Kelly BP, Wartzok D (1996) Ringed seal diving behavior in the breeding season. Can J Zool 74:1547-1555

Kenyon KW (1981) Monk seals Monachus Fleming, 1822. In: Ridgway SH, Harrison RJ (eds) Handbook of marine mammals, Vol. 2, Seals. Academic Press, London, p 195-220

Kenyon KW, Rice DW (1959) Life history of the Hawaiian monk seal. Pac Sci 13:215-252

King JE (1983) Seals of the world. Oxford Univ Press, Oxford

Kingsley MCS, Stirling I (1991) Haul-out behaviour in ringed and bearded seals in relation to defence against surface predators. Can J Zool 69:1957-1861

Kleiber M (1975) The fire of life: an introduction to animal energetics. Robert E Krieger Publishing Co, Huntington, NY

Kooyman GL, Drabek CM (1968) Observations on milk, blood, and urine constituents of the Weddell seal. Physiol Zool 41:187-194

Kovacs KM (1987a) Maternal behaviour and early behavioural ontogeny of harp seals, Phoca groenlandica. Anim Behav 35:844-855

Kovacs KM (1987b) Maternal behaviour and early behavioural ontogeny of grey seals (Halichoerus grypus) on the Isle of May, UK. J Zool Lond 213:697-715

Kovacs KM (1990) Mating strategies in male hooded seals (Cystophora cristata). Can J Zool 68:2499-2502

Kovacs KM (1995a) Mother-pup reunions in harp seals, Phoca groenlandica cues for the relocation of pups. Can J Zool 73:843-849.

Kovacs KM (1995b) Harp and hooded seals - a case study in the determinants of mating systems in pinnipeds. In: Blix 
$A S$, Walløe $L$, Ulltang $\varnothing$ (eds) Whales, seals, fish and man Elsevier Science BV, Amsterdam, p 329-336

Kovacs KM, Lavigne DM (1985) Neonatal growth and organ allometry of Northwest Atlantic harp seals (Phoca groenlandica). Can J Zool 63:2793-2799

Kovacs KM, Lavigne DM (1986) Maternal investment and neonatal growth in phocid seals. J Anim Ecol 55: $1035-1051$

Kovacs KM. Lavigne DM (1992) Mass-transfer efficiency between hooded seal (Cystophora cristata) mothers and their pups in the Gulf of St. Lawrence. Can J Zool 70: $1315-1320$

Kovacs KM, Lavigne DM, Innes S (1991) Mass transfer efficiency between harp seal (Phoca groenlandica) mothers and their pups during lactation. J Zool Lond 223:213-221

Kovacs KM, Lydersen C, Gjertz I (1996) Birth-site characteristics and prenatal molting in bearded seals (Erignathus barbatus). J Mammal 77:1085-1091

Kretzmann MB, Costa DP, LeBoeuf BJ (1993) Maternal energy investment in elephant seal pups: evidence for sexual equality? Am Nat 141:466-480

Lavigne DM, Kovacs KM (1988) Harps \& Hoods: ice-breeding seals of the Northwest Allantic. University of Waterloo Press, Waterloo

Lavigne DM, Stewart REA (1979) Energy content of harp seal placentas. J Mammal 60:854-856

Lawson JW, Renouf D (1987) Bonding and weaning in harbor seals, Phoca vitulina. J Mammal 68:445-449

LeBoeuf BJ, Costa DP, Huntley AC, Feldkamp SD (1988) Continuous, deep diving in female northern elephant seals, Mirounga angustirostris. Can J Zool 66:446-458

Lipps JH, Mitchell E (1976) Trophic model for the adaptive radiations and extinctions of pelagic marine mammals. Paleobiol 2:147-155

Lydersen C (1991) Monitoring ringed seal (Phoca hispida) activity by means of acoustic telemetry. Can J Zool 69: $1178-1182$

Lydersen C (1995) Energetics of pregnancy, lactation and neonatal development in ringed seals (Phoca hispida). In: Blix AS, Walløe L, Ulltang $\varnothing$ (eds) Whales, seals, fish and man. Elsevier Science BV, Amsterdam, p 319-327

Lydersen C, Gjertz I (1986) Studies of the ringed seal (Phoca hispida Schreber, 1775) in its breeding habitat in Kongsfjorden, Svalbard. Polar Res 4:57-63

Lydersen C, Hammill MO (1993a) Diving in ringed seal (Phoca hispida) pups during the nursing period. Can $\mathrm{J}$ Zool 71:991-996

Lydersen C, Hammill MO (1993b) Activity, milk intake and energy consumption in free-living ringed seal (Phoca hispida) pups. J Comp Physiol B 163:433-438

Lydersen C, Kovacs KM (1993) Diving behaviour of lactating harp seal, Phoca groenlandica, females from the Gulf of St. Lawrence, Canada. Anim Behav 46:1213-1221

Lydersen C, Kovacs KM (1995) Paralysis as a defence response to threatening stimuli in harp seals (Phoca groenlandica). Can J Zool 73:485-492

Lydersen C. Kovacs KM (1996) Energetics of lactation in harp seals (Phoca groenlandica) from the Gulf of St. Lawrence, Canada. J Comp Physiol B 166:295-304

Lydersen C, Ryg M (1991) Evaluating breeding habitat and populations of ringed seals Phoca hispida in Svalbard fiords. Polar Rec 27:223-228

Lydersen C. Smith TG (1989) Avian predation on ringed seal Phoca hispida pups. Polar Biol 9:489-490

Lydersen C, Jensen PM, Lydersen E (1990) A survey of the Van Mijen fiord, Svalbard, as habitat for ringed seals, Phoca hispida. Holarct Ecol 13:130-133
Lydersen C, Hammill MO, Ryg MS (1992a) Water flux and mass gain during lactation in free-living ringed seal (Phoca hispida) pups. J Zool Lond 228:361-369

Lydersen C. Ryg MS, Hammill MO, O' Brien PJ (1992b) Oxygen stores and aerobic dive limit of ringed seals (Phoca hispida). Can J Zool 70:458-461

Lydersen C. Hammill MO, Ryg MS (1993) Differences in haulout pattern in two nursing ringed seal (Phoca hispida) pups. Fauna Norv Ser A. 14:47-49

Lydersen C, Hammill MO, Kovacs KM (1994a) Activity of lac tating ice-breeding grey seals, Halichoerus grypus, from the Gulf of St. Lawrence, Canada. Anim Behav 48 $1417-1425$

Lydersen C. Hammill MO, Kovacs KM (1994b) Diving activity in nursing bearded seal (Erignathus barbatus) pups. Can J Zool 72:96-103

Lydersen C, Hammill MO, Kovacs KM (1995) Milk intake, growth and energy consumption in pups of ice-breeding grey seals (Halichoerus grypus) from the Gulf of St Lawrence, Canada. J Comp Physiol B 164:585-592

Lydersen C, Kovacs KM, Hammill MO, Gjertz I (1996) Energy intake and utilisation by nursing bearded seal (Erignathus barbatus) pups from Svalbard, Norway. J Comp Physiol B 166:405-411

Lydersen C, Kovacs KM, Hammill MO (1997) Energetics during nursing and early postweaning fasting in hooded seal (Cystophora cristata) pups from the Gulf of St. Lawrence. Canada. J Comp Physiol B 167:81-88

McLaren IA (1960) Are the pinnipedia biphyletic? Syst Zool 9 $18-28$

McLaren IA (1975) A speculative overview of phocid evolution. Rapp PV Reun Cons Int Explor Mer 169:43-48

Nansen $F(1898)$ The first crossing of Greenland. Longman, Green \& Co, London

Nansen F (1925) Hunting adventures in the Arctic. JM Dent \& Sons, Ltd, London

Oftedal OT, Boness DJ, Tedman RA (1987) The behavior, physiology, and anatomy of lactation in the pinnipedia. In: Genoways HH (ed) Current mammalogy, Vol 1. Plenum Press, New York, p 175-245

Oftedal OT, Boness DJ, Bowen WD (1988) The composition of hooded seal (Cystophora cristata) milk: an adaptation for postnatal fattening. Can J Zool 66:318-322

Oftedal OT, Bowen WD, Widdowson EM, Boness DJ (1991) The prenatal molt and its ecological significance in hooded and harbor seals. Can J Zool 69:2489-2493

Oftedal OT, Bowen WD, Boness DJ (1993) Energy transfer by lactating hooded seals and nutrient deposition in their pups during the four days from birth to weaning. Physiol Zool 66:412-436

Oftedal OT, Bowen WD, Boness DJ (1996) Lactation performance and nutrient deposition in pups of the harp seal, Phoca groenlandica, on ice floes of southeast Labrador. Physiol Zool 69:635-657

Øritsland NA (1970) Energetic significance of absorption of solar radiation in polar homeotherms. In: Holdgate MW (ed) Antarctic ecology, Vol 1 Academic Press, London, p $464-479$

Pastukhov VN (1975) Number and distribution of the postparturent females of the Baikal seal. Fish Mar Serv Transl Ser 3544:105-110

Perry EA, Stenson GB (1992) Observations on nursing behaviour of hooded seals, Cystophora cristata. Behaviour 122: $1-10$

Perry EA, Carr SM, Bartlett SE, Davidson WS (1995) A phylogenetic perspective on the evolution of reproductive behavior in pagophilic seals of the northwest Atlantic as 
indicated by mitochondrial DNA sequences. $J$ Mammal $76: 22-31$

Rasa OAE (1971) Social interaction and object manipulation in weaned pups of the northern elephant seal Mirounga angustirostris. Z Tierpsykol 29:82-102

Ray CE (1976) Geography of phocid evolution. Syst Zool 25 391-406

Reeves RR, Stewart BS, Leatherwood S (1992) The Sierra Club handbook of seals and sirenians. Dai Nippon Printing Co, Ltd, Hong Kong

Reiter J, Stinson NL, LeBoeuf BJ (1978) Northern elephant seal development: the transition from weaning to nutritional independence. Behav Ecol Sociobiol 3:337-367

Renouf D, Diemand D (1984) Behavioural interactions between harbour seal mothers and pups during weaning (pinnipeds: Phocidae). Mammalia 48:53-58

Renouf D, Lawson JW (1986) Play in harbour seals (Phoca vitulina). J Zool Lond 208:73-82

Renouf D, Lawson JW (1987) Quantitative aspects of harbour seal (Phoca vitulina) play. J Zool Lond 212:267-273

Renouf D, Lawson J, Gaborko L (1983) Attachment between harbour seal (Phoca vitulina) mothers and pups. J Zool Lond 199:179-187

Repenning CA (1976) Adaptive evolution of sea lions and walruses. Syst Zool 25:375-390

Repenning CA (1980) Warm-blooded life in cold oceans. Oceans 13:18-24

Repenning CA, Ray CE, Grigorescu D (1979) Pinniped biogeography. In: Gray J, Boucot AJ (eds) Historical biogeography, plate tectonics, and the changing environment. Proc 37 th Ann Biol Colloquium, Corvallis, Oregon, 1976. Oregon State Univ Press, Corvallis, OR, p 357-369

Riedman M, Ortiz CL (1979) Changes in milk composition during lactation in the northern elephant seal. Physiol Zool 52:240-249

Römer F, Schaudinn F (1900) Plan des Werkes und Reisebericht. II. Die Landtiere und die Eistiere. Fauna Arctica 1: $1-84$

Ryg M, Lydersen C, Markussen NH, Smith TG, Øritsland NA (1990a) Estimating blubber content of phocid seals. Can J Fish Aquat Sci 47:1223-1227

Ryg M, Smith TG, Øritsland NA. (1990b) Seasonal changes in body mass and body composition of ringed seals (Phoca hispida) on Svalbard. Can J Zool 68:470-475

Scheffer VB, Slipp JW (1944) The harbor seal in the Washington State. Am Midl Nat 32:373-416

Schreer JF, Testa JW (1995) Statistical classification of diving behavior. Mar Mammal Sci 11:85-93

Shepeleva VK (1973) Adaptations of seals to life in the Arctic. In: Chapskii KK, Sokolov VE (eds) Morphology and ecology of marine mammals. Israel Progr Sci Transl, Jerusalem. John Wiley \& Sons, New York, p 1-58

Smith TG (1976) Predation of ringed seal pups (Phoca hispida) by the arctic fox (Alopex lagopus). Can J Zool 54: $1610-1616$

Smith TG (1980) Polar bear predation of ringed and bearded seals in the land-fast sea ice habitat. Can J Zool 58: 2201-2209

Smith TG (1987) The ringed seal, Phoca hispida, of the Canadian western Arctic. Can Bull Fish Aquat Sci 216:1-81

Smith TG, Stirling I (1975) The breeding habitat of the ringed

Editorial responsibility: Otto Kinne (Editor),

Oldendorf/Luhe, Germany seal (Phoca hispida). The birth lair and associated structures. Can J Zool 53:1297-1305

Smith TG, Hammill MO, Taugbol G (1991) A review of the developmental, behavioural and physiological adaptations of the ringed seal, Phoca hispida, to life in the arctic winter. Arctic 44:124-131

Stewart REA (1987) Behavioural reproductive effort of nursing harp seals Phoca groenlandica. J Mammal 68(2): $348-358$

Stewart REA, Lightfoot N, Innes S (1981) Parturition in harp seals. J Mammal 62:845-850

Stirling I (1974) Midsummer observations on the behaviour of wild polar bears (Ursus maritimus). Can J Zool 52: 1191-1198

Stirling I (1975) Factors affecting the evolution of social behaviour in the Pinnipedia. Rapp PV Reun Cons Int Explor Mer 169:205-212

Stirling I (1977) Adaptations of Weddell and ringed seals to exploit the polar fast ice habitat in the absence and presence of surface predators. In: Llano GA (ed) Adaptations within Antarctic ecosystems. Proc 3rd SCAR Symp Antarct Biol, Washington, DC, August 26-30, 1974. Gulf Publishing Company, Houston, p 741-748

Stirling I (1983) The evolution of mating systems in pinnipeds. In: Eisenberg JF (ed) Advances in the study of behavior. Spec Publ Amer Soc Mammal 7, p 489-527

Stirling I, Latour PB (1978) Comparative hunting abilities of polar bear cubs of different ages. Can J Zool 56: $1768-1772$

Sullivan RM (1982) Agonistic behavior and dominance relationships in the harbor seal, Phoca vitulina. J Mammal 63 : $554-569$

Taugbøl G (1984) Ringed seal thermoregulation, energy balance and development in early life. Can Fish Aquat Sci Transl Ser 5090:1-109

Tedford RH (1976) Relationships of pinnipeds to other carnivores (Mammalia). Syst Zool 25:363-374

Tedman RA, Bryden MM (1979) Cow-pup behaviour of the Weddell seal, Leptonychotes weddellii (Pinnipedia), in McMurdo Sound, Antarctica. Aust Wildl Res 6:19-37

Tinker MT, Kovacs KM, Hammill MO (1995) The reproductive behavior and energetics of male gray seal (Halichoerus grypus) breeding on a land-fast ice substrate. Behav Ecol Sociobiol 36:159-170

Trillmich F (1996) Parental investment in pinnipeds. Adv Study Behav 29:533-577

True FW (1906) Description of a new genus and species of fossil seal from the Miocene of Maryland. US Natl Mus Proc 5:835-840

Venables UM, Venables LSV (1955) Observations on a breeding colony of the seal Phoca vitulina in Shetland. Proc Zool Soc Lond 125:521-532

Wilson EO (1975) Sociobiology: the new synthesis. Harvard Univ Press, Cambridge

Wilson S (1974) Juvenile play of the common seal Phoca vitulina vitulina with comparative remarks on the grey seal Halichoerus grypus. Behaviour 48:37-60

Worthy GAJ (1987) Metabolism and growth of young harp and grey seals. Can J Zool 65:1377-1382

Wyss AR (1988) Evidence from flipper structure for a single origin of pinnipeds. Nature 334:427-428

Submitted: December 10, 1998; Accepted: May 20, 1999

Proofs received from author(s): September 16, 1999 